Authors' copy. The original article has been published in Geopolitics 17:1, doi:

$10.1080 / 14650045.2016 .1208654$. For citation, please use the original.

\title{
Geosocial Lives in Topological Polis: Mohamed Bouazizi as a Political Agent
}

\begin{abstract}
Geopolitical events and developments can hardly be detached from the mundane lives where people confront politicized and politicizing matters, share meaningful experiences, build attitudes, and take action. To contribute to understanding how large-scale geopolitics connect with the everyday, this article draws attention to political subjectivity as the condition of possibility of political agency and polis as the geosocial context of political life as experienced, conceived, and practiced. Empirically, the paper engages with the tragic end of Mohamed Bouazizi's life and scrutinizes his role in the events and developments generally known as the Arab Spring. Our analysis contests both the dominant interpretation that postulates political import to his acts, and the alternative account that underscores his apolitical stance. Instead, we propose that the international politicization of M ohamed Bouazizi's agency unfolded as an accomplishment of many individual and collective actors, including Bouazizi himself in his struggle to cope with emergent aspects of his everyday life.
\end{abstract}

\section{Introduction}

The tragic suicide of Mohamed Bouazizi in the small Tunisian town of Sidi Bouzid on 17 December 2010 has gained global significance as an event claimed to have led to the still-ongoing extensive political mobilization known as the 'Arab Spring'. For analysts, the act and its consequences have evidenced the ways in which geopolitical processes bring together multiple issues and events, such as historical layers of colonialism, autocratic regimes in North-African countries, problems of urban survival in the face of restricted possibilities and petty corruption, the power of social media in transmitting images and stories of injustice, and ultimately the sacrificial body of a fruit vendor who struggled to make a living in dire circumstances. ${ }^{1}$

Indeed, few scholars would deny the geopolitical efficacy of Bouazizi's act. In what has become almost a canonical account, humiliated Mohamed Bouazizi set himself alight out of despair in front of Sidi Bouzid M unicipal Office after his merchandise had been confiscated by a police officer on arbitrary grounds and his appeal to the local authorities for the return of his property had been disregarded. The ensuing local protests against Bouazizi's grievances and mistreatment were caught on mobile phone photos and videos, and circulated through social media, which eventually sparked an upheaval spreading across Tunisia, other Arab countries, and beyond. ${ }^{2}$ This is how the Arab Spring uprising erupted, the argument goes in an expanding literature. 
Authors' copy. The original article has been published in Geopolitics 17:1, doi: 10.1080/14650045.2016.1208654. For citation, please use the original.

There are different interpretations in regard to the exact causes and consequences related to the rise of Arab Spring, but the broader political importance of Bouazizi's suicide seems evident. ${ }^{3}$ However, the question as to whether the act in itself was political is more controversial. For example, in assessing the meaning of Bouazizi's action, Fassin sees the event as a demonstration of "how political subjectivity may respond and overcome political subjection", but then notes more cautiously that we do not really know whether "when committing the gesture of burning himself, M ohamed Bouazizi was entirely and explicitly conscious of its signification". He nevertheless ends up aligning Bouazizi with "men and women who sacrifice their life for their cause", thus portraying his act as a deliberately political one. ${ }^{4}$

A more skeptical reading is proposed by Lim who argues that, rather than the death itself, it was the ways in which it was skillfully framed that triggered a broad process of mobilization bridging diverse social groups across class divisions and regional disparities in the Tunisian society. ${ }^{5}$ In a key role here was Ali Bouazizi, a long-time political activist (not kin to Mohamed Bouazizi), who realized that without a compelling narrative M ohamed's case would soon be forgotten, just like several other recent desperate acts of similar nature. As he later admitted, he added to Mohamed Bouazizi's story elements, or "white lies", that portrayed him as a university graduate forced to work on the streets and contemptuously slapped in the face by a female police officer. ${ }^{6}$ These two ingredients of the story resonated strongly among a broad array of "young people of Tunisia whose rights and freedom were denied" as well as internationally among many people who "were a world away from Tunisia".7 While Mohamed Bouazizi's suicide was an important act in itself, Lim contends, it was only the amended story that succeeded in politicizing his burning body. ${ }^{8}$

Approaching the event from a different angle, De Soto sets out to reveal "the real M ohamed Bouazizi" as "an apolitical family man" and "the very opposite of an activist". ${ }^{9}$ In depicting Bouazizi's life and values, he underlines that Bouazizi was first and foremost an entrepreneur whose "talent was for buying and selling". His life revolved around the need to support his mother and siblings through small-scale street vending that, due to prevailing circumstances, was doomed to operate as part of the extralegal local economy. ${ }^{10}$ Even though a "repressed entrepreneur", he had a reputation for "shrewd practicality" and "was trusted by his peers". His dreams related to expanding his business and establishing a "permanent stand at the wholesale market". Hence, as De Soto points out, it was Bouazizi's business and future livelihood that were attacked by the corrupt local authorities, rather than his views or convictions concerning Tunisian politics. ${ }^{11}$

In this article, we want to contest both the dominant interpretation that postulates political import to Bouazizi's act on 17 December 2010 and the alternative account that underscores his apolitical stance. To this end, we will employ the idea of a geosocial constitution of political 
Authors' copy. The original article has been published in Geopolitics 17:1, doi:

10.1080/14650045.2016.1208654. For citation, please use the original.

subjectivity. It allows us to rethink the notion of 'the political' in the context of mundane action while keeping with the understanding that matters of importance in the lives of ordinary people may animate open-ended processes that bundle together issues, events, and situations near and far. This means identifying geosociality as a complementary dimension to geopolitical and geoeconomic approaches, with particular emphasis on experiential aspects in the constitution of the political.

In exploring M ohamed Bouazizi's case, we set out to discuss subjectivity as a human condition that provides people capacities to lead their lives as political subjects. Within the study of geopolitics we, hence, join in the scholarship that is increasingly focusing on the everyday in an attempt to understand how political processes unfold, and are enacted, in people's lived worlds. ${ }^{12}$ We consider mundane political life as primarily geosocial in the sense that people negotiate all their roles and identities contextually in the communities where they lead their lives. To grasp the complexities of geosocial contextuality we approach people's experiential worlds as topologically constituted spaces that we term 'polis'. M oving beyond territorial connotations, we conceive of polis as a relational space that ties together people, issues, events, ideologies, places, and objects connected by matters that gain importance in its life. As M ohamed Bouazizi's case testifies, political subjectivities embedded in a polis constitute a dynamic space where unexpectedly politicized matters, surprising actions, and unforeseeable developments traversing various temporal and spatial scales may take place.

We begin the paper with a conceptual introduction to our conception of political subjectivity and present some key questions that this pragmatist approach opens up regarding mundane politics. This is followed by a discussion concerning polis as a topological setting of political life. By discussing Mohamed Bouazizi's case, we then consider how politics can be appreciated as an emergent aspect of geosociality. Finally, in conclusion we propose a relational approach to studying politics as it unfolds in people's lived realities.

\section{What is political subjectivity?}

Interest in political subjectivity has gained momentum in social sciences in recent years. This has been fueled by the need to develop a better understanding of a variety of individual and collective ways of acting politically and impacting on power relations. ${ }^{13}$ Seen through different disciplinary traditions and divergent, even contradictory, theoretical frameworks, the connotations of political subjectivity range from socially constituted power relations to embodied singular experience, from emotional and affective dynamism to psychological processes and states. ${ }^{14}$ Yet, what most theories agree on is that the idea of political subjectivity cannot operate on a received 'substantialist' notion 
Authors' copy. The original article has been published in Geopolitics 17:1, doi:

10.1080/14650045.2016.1208654. For citation, please use the original.

of the subject and that it is important to appreciate the relational dynamics through which political subjectivities emerge. ${ }^{15}$

$M$ any contemporary theories of subjectivity are challenged by the impasse of having to choose either to emphasize experience at the cost of downplaying its social constitution, or to underline the social constitution of subjectivity at the cost of the individuality or singularity of experience. M oreover, attempts to solve this conundrum have tended to lead scholars to undermine the "complexity and ambivalence that inhere in subjectivity, leaving assumptions about the latter's transparency unquestioned". 16

To move beyond this impasse, we approach subjectivity as the elusive yet capacious dynamism that allows the subject not to collapse with the forces that constitute it, be these intersubjective formation of identities or positioning related to social roles. In unraveling this dynamism we have sought inspiration from the thought of G.H. Mead, who has proposed an analytical distinction between two distinct yet interdependent facets of the subject, composed as a continuous dialogue between the subject's ' $I$ ' and 'me'. ${ }^{17}$ Here 'I' refers to the subject's always presently ongoing embodied action and factual being in the world, now and here. Its particularity lies in the fact that, as a facet of being, 'l' escapes any capture by conscious thought because it is precisely the aspect in us presently carrying out the act of thinking. Any attempt to 'think about oneself thinking' immediately turns toward the other facet of the subject that Mead refers to as 'me'. Here 'me' is the subject as an object that can be captured by thought, by oneself or by others. It is the interface of our social existence where we negotiate between our own sense of self and our identities as portrayed back to us, in our interactions with others. Whereas 'l' cannot be shared, 'me' is social throughout because our sense of self is produced intersubjectively in our encounters with others during the course of our lives.

The distinction between ' $I$ ' and 'me' helps in balancing between the socially constituted and experiential aspects of subjectivity without assuming full transparency to experienced subjectivity. ${ }^{18}$ This is so especially because, as subjective subjects, we are always amalgamations of these two facets that can be distinguished only analytically. Yet, the understanding of subjectivity as a dialogue between unique embodied being and social existence is vitally important for our attempts to understand political subjectivity since it explains why the subject cannot be fully collapsed either to its singular embodiment or to the forces of its sociocultural constitution. The dynamism between ' $I$ ' and 'me', as a baseline understanding of subjectivity, sustains the possibility for human beings to experience identities and subject positions instead of simply enacting and living them through. ${ }^{19}$ In other words, we can conceive of political subjectivity as a relative distance from the identity markers and subject positions we encounter in our social lives. This enables us to become attentive to social 
Authors' copy. The original article has been published in Geopolitics 17:1, doi:

10.1080/14650045.2016.1208654. For citation, please use the original.

power relations embedded in particular subject positions that we may accept, avert, or seek to transform. This capacity - at once socially embedded, experiential, and intuitive - we refer to as political subjectivity.

Hence, M ohamed Bouazizi's sense of self, too, was always irreducible to the many identities through which we have come to know him (e.g. young, male, sibling, street vendor, entrepreneur), regardless of how strongly these identity markers were etched to his body or embedded in his mind. It is precisely the element of relative autonomy from forces of subjection, we contend, that affords all human beings the ability to experience subjecthood and become attuned to identities and roles that feel uncomfortable, abusive, or oppressive. This human capacity allows for an important leeway from total subordination in the challenging situations that people encounter in their lives. Importantly, and as Mohamed Bouazizi's situation clearly testifies, the possibility to experience identities and subject positions does not necessarily entail a fully reflexive or cognitively rationalized position taking. Therefore, the outcomes of political subjectivities remain undetermined and relate to political attitudes and actions in open-ended ways. Because of political subjectivities there is potential to spontaneous agency as people participate in social life, not as assemblages of categorical features, but as subjective subjects who share a social world. ${ }^{20}$

The elementary importance of subjectivity as a capacity to experience one's social self becomes particularly evident when the capacity is lacking. This is the case for instance with personality disorders characterized by a diffuse sense of identity and oneself. As Jørgensen explains, a diffuse sense of self will "compromise the individual as a competent (autonomous) subject and actor" because one loses "not only a sense of who one is, but also a sense of who one isn't and doesn't wish to become". ${ }^{21}$ The phenomenologically oriented psychological and psychoanalytic works that Jørgensen draws from ${ }^{22}$ identify the same problem that social and political theorists of subjecthood have acknowledged: With marginal ability to relate with their social selves people have very limited access to social life as unique persons. ${ }^{23}$ Yet, as Arendt states, uniqueness is an essential characteristic of the homo politicus as it justifies relative equality as one of the leading principles in democratic life: "We are all the same, that is, human, in such a way that nobody is ever the same as anyone else who lived, lives, or will live." 24

By referring to an anomaly, we do not want to say that people with mental problems have no capacities to political agency in their mundane settings. Indeed, as subjectivities are always relative, it is difficult to envision a personality disorder as an absolute state of non-subjectivity. Thus, it is reasonable to assume that personal desires and attitudes, as well as purposive and intentional acts of caring and defiance arise in settings like therapeutic institutions, albeit in forms that reflect the particular circumstances. ${ }^{25}$ Still less are we suggesting that all politics can be traced down to people's 
Authors' copy. The original article has been published in Geopolitics 17:1, doi:

10.1080/14650045.2016.1208654. For citation, please use the original.

subjective relations with their identities and subject positions. As we will discuss below, political subject formation, the development of political attitudes, and the practice of political agency are all important facets of political life. Yet if 'the political' is taken to mean contextual importance, like we have come to think about it, the connection between subjectivity and politics can be traced analytically and this methodological understanding can then be found useful empirically too. But how does politics as contextual importance emerge? Tackling this question requires that we introduce the idea of a topological polis.

\section{What is topological polis?}

We propose polis as a concept to capture the topological settings of political life, thus detaching it from city-statist and territorial connotations. Arendt's political-philosophical work has been pathbreaking in enlivening it into a spatially open-ended and socially defined concept. In Human Condition, she describes polis as "the organization of people as it arises out of acting and speaking together, and its true space lies between people living together for this purpose, no matter where they happen to be". ${ }^{26}$ This basic idea has developed further in the works of some current scholars who have set out to reimagine polis with different conceptions of 'the political' and spatiality, leading to a number of slightly different interpretations. ${ }^{27}$

We deem it important to emphasize that polis is a relational space that bundles together people, issues, events, ideologies, places and objects, here and there, now, before and in the future. It is a constitutive context for people's view of themselves and (significant) others, influencing their understandings, awareness, and attentiveness and thus shaping them as political subjects. Polis is neither randomly constituted nor does it follow a singular spatial logic, such as territoriality, network, or 'flatness'. Its constituents are brought together by matters that gain importance in polis - issues that politicize and are politicized in a given geosocial realm - making it a dynamic space with a constantly changing shape and composition. Yet it is not a fluid reality where nothing holds its place. As in the case of M ohamed Bouazizi, while hardly anyone could have foreseen his suicide, it did not come out of the blue either. Many challenging aspects in his lived reality had to do with the prevailing economic situations in Tunisia and the non-democratic North African and Middle Eastern societies, which continue to marginalize people, even if in different ways and for different reasons.

This said we do not seek to link Bouazizi's life or acts with the rise of the Jasmine revolution or the broader Arab Spring mobilization in any simple way. As M abrouk aptly notes, "any analysis of a revolutionary situation is always characterised by a degree of uncertainty, particularly in terms of the potential reasons adduced to explain its emergence" ${ }^{28}$ We rather set forth an alternative 
Authors' copy. The original article has been published in Geopolitics 17:1, doi:

10.1080/14650045.2016.1208654. For citation, please use the original.

perspective, highlighting that people's actions as part of their everyday struggles are significant forms of mundane politics in themselves, independently of their possible ramifications in broader political contestations. Overlooking politics as experienced by its actors, we contend, may lead to the objectification and postulation of political subjects as mere pieces in a game in which they actually had no role to play. The geosocial aspects of their mundane politics are then undermined in favor of a predominantly geopolitical reading. ${ }^{29}$ Hence, for M ohamed Bouazizi too, his actions took place in the context of an emergent lived world with a history of successes and failures, better and worse future prospects, position taking, individual and collective negotiation of justness and injustice, being seen and seeing others. ${ }^{30}$

This contextuality of mundane politicization, whereby matters become important and those involved have something at stake in them, captures well what we refer to with the term polis. Belonging in a polis consists of a dynamic set of relationships with differing intensities. Some of these start to develop early on within the geosocial realm where one lives. Others are made up in later phases of life as one's living environments diversify and change, and new social connections and spatial attachments come about. As a relational space, polis is neither reducible to individual experiential life-worlds, nor conceivable as an entity that exists independently of those who constitute it. Thus, to make sense of Bouazizi's suicide as an act carried out in a polis, it is impossible to disregard his life experiences as a street vendor trying to get along in the local extralegal business, any more than it is feasible to overlook the complex sociocultural and geopolitical settings in which he gained these experiences.

Through his involvement in his trade, Bouazizi had become entangled in a precarious street life, which entailed picking up "fruits and vegetables from the local wholesale market", but also "harassment at the hands of deeply corrupt petty officials". ${ }^{31}$ As Frische notes on the basis of his ethnographic work among Tunisian street vendors, their lives are typically characterized by everyday struggles of 'getting by', meaning the development of "informal tactics that use the few economic opportunities available" in the segregated and poor urban peripheries in Tunisia. ${ }^{32}$ Street vending plays an important role as it allows for the circulation of foodstuffs and affordable goods in peripheral neighborhoods that the formal retail circuits cannot adequately serve. ${ }^{33}$ Therefore, those who practice informal vending are often valued in their own communities as persons willing to work in peripheral urban areas to secure their economic survival. Yet, as street vending is usually practiced without any formal licensing, it "involves the risk of facing controls by the municipality police". ${ }^{34}$

It is this world of local solidarity, economic survival, and fear for authorities that was the focal point for M ohamed Bouazizi's daily struggles, more than the broader questions of democracy that the scholarship on the Arab Spring has tended to emphasize. ${ }^{35}$ As a polis situated at the margins of 
Authors' copy. The original article has been published in Geopolitics 17:1, doi:

10.1080/14650045.2016.1208654. For citation, please use the original.

legality, it brought together particular orders and norms, institutions, artefacts, and immaterial items that all took part in its mobilization. As much as 'in here' - as incorporated in urban life, collective memories, moralities, and human bodies - the polis was always already 'out there' - as embedded in institutions, buildings, treaties, streets, and markets, thus constituting for Bouazizi the "everyday socio-spatial context [...] from which local micro-politics can emerge". ${ }^{36}$

In its social scientific meaning topology refers to socially constituted spatial configurations. ${ }^{37}$ Following this idea, we consider the political life of polis as primarily geosocially established, with two consequences on how mundane politics may unfold. First, when some idea, thing, act, or role is politicized in polis it does not become political in general or for good. Considering the many selfimmolations in Tunisia in 2010, of which Bouazizi's is the one we know most about, it is clear that, whatever the circumstances in which these clearly purposive acts took place, they resonated in very different ways in their respective polises. ${ }^{38}$ Second, anything that gains importance in people's lived worlds is potentially political, but to turn political they must be politicized in the polis that lends them their importance. Issues once politicized may hence also cease to appear as political if their recognized importance fades. That is, what is or is not political is contextual throughout.

Therefore, even though Bouazizi's suicide may now seem self-evidently political - either as a political act in itself or as an act politicized by activists - to understand the dynamism of politicization in his actions we need to regard the polis of his lived world. ${ }^{39}$ This means bringing an experiential perspective to politics along with other understandings that inform the analysis of the Arab Spring, including historical, democratic, revolutionary, and cultural perspectives. ${ }^{40}$ We also need to recognize that the politics of his act might necessarily not have resonated in the Tunisian society, or in the Arab or the Western worlds, the way they did. ${ }^{41}$ This already hints that processes of politicization are not disconnected, any more than polises are completely separate entities.

Political meanings travel, as the constituents of a given polis are influential in other geosocial worlds. Politicization may hence spread from one spatial configuration to others, swiftly or gradually, depending on the activeness and connectedness of their constituents. For example, the ways in which M ohamed Bouazizi's suicide quickly became news in social media, news media, and among the population in Tunisia and beyond has been well documented. ${ }^{42}$ Besides a highly appealing narrative, key in the process were the hybrid (informal and formal) networks of communication that were influential in turning Bouazizi's suicide into a political movement, generating both collective action on the ground in Tunisia and other Northern African countries, and connective action spanning worlds away from Tunisia. ${ }^{43}$

Where polises intersect, people may take positions and act in translocal and -national networks and by so doing enhance certain 'political drifts'. For example, human rights principles may 
Authors' copy. The original article has been published in Geopolitics 17:1, doi:

10.1080/14650045.2016.1208654. For citation, please use the original.

travel from one context to another as part of institutional practices, endangered species may be broadly politicized through new media applications that provide them global visibility, and illicit practices of extralegal economy may be considered legitimate when it is understood that for some young individuals they provide the sole source of income available. In these and other cases, when the importance of the matter is recognized by different people whose lives need not be previously connected, it may politicize well beyond its remit, which is what happened in the Arab Spring uprisings. ${ }^{44}$ This is how geosociality, as a topological dynamism of lived realities, is directive to political life.

As a topological space that bundles together issues, events, ideologies, objects, and places polis is never composed of humans alone and thus does not parallel with notions like civil society or community. However, in anchoring mundane politics to subjectivities and contextually emerging importance, we wish to underline that its political meanings are always generated by people. Sexual orientations, for instance, are not political because they exist; they are political because some people in certain contexts have found them particularly important and their related activities have led to broad politicizations. ${ }^{45}$ Similarly, the self-immolation of M ohamed Bouazizi was not a political matter until it was identified as such in a polis that shared his desperation. For us this underscores the fundamentally geosocial nature of politics. Politicization is always based on contextual social life involving subjective human beings who are capable of "beginning something new", to use Arendt's terms, i.e. introducing new matters of importance and acknowledging new influential aspects in their lived worlds. ${ }^{46}$

\section{Politics as contextual importance}

We will now turn back to the question of contextual importance as the driver of politics in topological polises. To account how particular issues or events gain importance in people's everyday lives we could seek to trace the learning processes involved. As people become attentive to things that matter to them, and share their experiences and thoughts with each other, they learn about and reconstitute politicizing and politicized issues in their geosocial realities. They may also develop attitudes for and against different matters, and take action when something becomes at stake in their worlds. From this perspective, politics can be actively encouraged and mobilized both in the form of information and practices ${ }^{47}$ Foreseeing the outcomes of such activities is, of course, not possible, because people form opinions subjectively and contextually, and their views are prone to change as they come across new aspects. People's willingness to take stances or to refrain from 
Authors' copy. The original article has been published in Geopolitics 17:1, doi:

10.1080/14650045.2016.1208654. For citation, please use the original.

taking sides in struggles concerning politicized matters also depends on their personal understandings and life situations.

Yet to suggest that political life is merely about learning (in a narrow sense as reconstitution and interpretation of existing information and understandings) would undermine its social character. ${ }^{48}$ First of all, as M iranda Fricker points out, to take up unpleasant or disturbing experiences there has to be a language available that enables these to be articulated and adequately understood. It may not be a straightforward process to gain such a language, as has been the case with subjugated groups such as indigenous communities and people with alternative sexual orientations. ${ }^{49}$ Moreover, people identify, create, and transmit conceptions about contextual importance primarily in and through the socially open-ended and emergent practices of their everyday lives. So like street vendors elsewhere in the Tunisian urban fringes, also M ohamed Bouazizi knew the importance of trust (with friends and colleagues), compliance (with the police and administrative authorities), care (with his family and friends), and pride (with his colleagues and customers) in the fabric of his lived reality. Raids against street vendors and the confiscation of their products and scales were common under Ben Ali's suppressive regime that, as a rule, included systematic and coded corruption and bribery. ${ }^{50}$ To manage with the local manifestations of the state - including the municipality, fiscal authorities, the police, and the employment center - the "vendors on the run" had to rely strongly on their "local networks of solidarity based on kinship, friendship and vicinity". ${ }^{51}$

Bouazizi encountered these matters every day in seeking to make a living and to improve his position in the extremely challenging circumstances. These issues, related to economic practice and control, mattered most to him. ${ }^{52}$ Broadly politicized issues like media censorship and violations of human rights and democracy in Tunisia, which he was aware of but did not actively follow, were not central issues in the polis of his street life..$^{53}$ Neither was education, regardless of the fact that he had to quit school at the age of 12 being responsible for the livelihoods of his five younger siblings perhaps understandably, considering that many people with education were nevertheless forced to enter the informal labor market. ${ }^{54}$ While significant, the gravity of these matters did not match the importance Bouazizi put to possibilities to work and to obtain a higher position in the local trade market, in order to gain a better opportunity to provide for his family.

Mohamed Bouazizi's encounters with arbitrary petty officials, who abused their power and demanded people's constant compliance, shows aptly how some geosocialities of political life can only be attained contextually. People who knew Bouazizi well attest that he was painfully aware of the inequalities and injustices characteristic to his working and living environment that placed him into a distressing position from which he had little opportunities to escape. ${ }^{55}$ His eagerness to do so was generally known among his colleagues who, while working under similar conditions, were not 
Authors' copy. The original article has been published in Geopolitics 17:1, doi:

10.1080/14650045.2016.1208654. For citation, please use the original.

quite as frustrated with the situation. Telling about Bouazizi's political subjectivity, he seems to have been particularly attentive to the arrogant abuse of power by people with little else to show than their institutional positions. Hence, the extent to which the Arab Spring can be seen as "Bouazizi's revolution", the events that sparked it were primarily about property rights, economic liberty, and human dignity. ${ }^{56}$

M ohamed Bouazizi worked hard to gather savings that would allow him to buy a car and a permanent stand, which was the only way he could gain more independence from the unpredictable and corrupt officials. In the events that preceded his radical act, this opportunity had been wiped out tout court, and with this, his prospects for a better future. In his position, he had few means to cover for the losses, and this would condemn him to stagnant or degrading life conditions. ${ }^{57}$ It was this geosocial setting where he took action. In a nutshell, as a political subject Bouazizi had a highly critical attitude toward the corruption that conditioned the local market in Sidi Bouzid and affected the life of those completely dependent on it. When his possibilities to ever break out from this subordinate position seemed to have died out, he acted against it by means that since became famous. In setting himself on fire in front of the town hall, he made his agony visible to the public administration responsible for the inequalities and injustices of his lived world, and shared it publically with other people.

With this close reading of Bouazizi's life situation, we wish to highlight that the development of political attitudes and the practice of politics is highly contextual and subjective. As contextual importance, politics is dependent on the embodied subjects who experience and relate subjectively with matters that appear important in polis. We emphasize individual subjects in this facet of political life as the only possible creators of political experiences, yet do not propose that political subjectivity could adequately be portrayed as encapsulated into the subject's inner life. This is so because our social existence is thoroughly intersubjectively constituted and our experiences are suffused with socially negotiated meanings. In other words, we are not pure embodied beings engaged with presently ongoing activity (' $I$ '), nor are we mere intersubjectively constituted social selves ('me'), but a constant dialogue between these two facets of subjectivity. The space for political subjectivity that thus opens up can further transform into shared political life when people create formations where collective experiences and self-understandings develop and new expressions are negotiated for articulate injustices. ${ }^{58}$

The analyzed case is illuminative also about the different geosocial dimensions of emergent politics. As people experience and relate with matters that are embedded in several polises at once, they bundle together various actors, issues, and events into topological constellations that can be traced through network analyses. M erlina Lim's detailed analysis about the events that followed 
Authors' copy. The original article has been published in Geopolitics 17:1, doi:

10.1080/14650045.2016.1208654. For citation, please use the original.

Bouazizi's suicidal act does exactly this. ${ }^{59}$ Following skillfully the chain of media actions and other practical events that mounted up into what is now known as Jasmine Revolution, she reveals the multiplicity of distinct individual and collective actors who participated in the politicization of Bouazizi's suicide and the subsequent revolutionary processes. As an elementary part of this struggle, she also considers the actors and activities that sought to hinder the politicization and preserve the status quo, most importantly Ben Ali's administration, the army, and the police. M oreover, her analysis acknowledges the key artefacts and infrastructures that made the protesting activities possible, hence covering those socio-cultural and material dimensions that formed an interface between Bouazizi's polis in Sidi Bouzid and those that involved the broader society in Tunisia and beyond.

As the winners of the struggle Lim displays the connected, or connective, networks of uneducated and educated Tunisians; activists and lay people; urban and rural inhabitants; people with distinct generational, gendered, and socio-economic positions; citizens and dwellers without a formal status; people with mobile phones and others with internet access; independent journalists, GNO reporters, and private bloggers; artists; Arab and Western medias; Tunisians living outside of Tunis; and other people around the world who expressed their support to the translocal and transnational revolutionary activities. It was this multilayered geosocial formation that sparked off the democratization process in Tunisia, which since has led to many ramifications beyond the country and the region. Hence, the international politicization of Mohamed Bouazizi did not just happen, but unfolded as an accomplishment of many individual and collective actors. While many self-immolations had occurred before in Tunisia and elsewhere in the Arabic world, these kinds of broad-ranging supralocal connective relations had not coalesced before.

In the framework introduced in this paper, these exceptional events can be understood as intersections between various polises. What concretely happened was that, within just a couple of days, numerous people in different geosocial realities were exposed to matters that perhaps were not directly part of their everyday lives, but still resonated strongly with what they felt as important. When the news about Bouazizi spread rapidly through various informal and formal channels all around the world, people could identify with him as a person placed into an unbearable position, they could align with his criticism toward unequal and humiliating treatment of hardworking people in precarious circumstances, and from the desperation of his act they could understand the fundamental wrongness of the society where he lived. In this way, massive amounts of people who had little in common with Bouazizi and each other suddenly found themselves sharing a world where they could take his position and the agony that he expressed through his final deed. This sharing of 
Authors' copy. The original article has been published in Geopolitics 17:1, doi:

10.1080/14650045.2016.1208654. For citation, please use the original.

political subjectivities was the driving force intersecting a rich constellation of differently constituted polises, and enabling the emergence of an interconnected but polymorphic revolutionary politics. ${ }^{60}$

\section{Conclusions}

In this paper, we have discussed Mohamed Bouazizi's case as an entry point to mundane politics, with emphasis on its three distinguishable yet interrelated facets. First, political subjects surface when people become attentive to matters of importance in their everyday environments, thus building subjective relations with their social selves and the issues that appear challenging to them. The human capability to experience identities and (in)justice is focal to this subject formation. Second, political attitudes arise as people relate with politicized and politicizing matters. This includes sharing personal experiences with others involved in the life of polis. Third, political action occurs when people act upon things that they find important and in so doing take part in struggles and negotiations concerning political life. This participation may concern generally politicized issues or seek to bring new matters to the fore, and it may range from oriented to purposive to intentional acts. ${ }^{61}$ In each of these dimensions, the experiential contexts of people's lives - their geosocial polises - condition their agency.

Approaching the discussed case in these terms has allowed us to challenge the interpretation that postulates political import to Bouazizi's activities, as well as the alternative account that underscores his stance as a thoroughly apolitical one. By highlighting people's mundane struggles as significant forms of politics, regardless of their broader ramifications, we have drawn attention to politics as experienced by its actors. To this end, we have portrayed politicization as embedded in the social life of polis where things, events, acts, artefacts, and people situationally gain import to varying degrees. This provides an alternative take on how Bouazizi's act of setting himself on fire in front of the Sidi Bouzid town hall can be understood as political agency.

Confronting politicized and politicizing matters, sharing meaningful experiences with others, building attitudes on this basis, and taking action when something alarming is happening are matters of interest in geopolitical research. While political spaces such as cities, states, border zones, and institutional sites are much studied as contexts of geopolitics, the experiential worlds of people's everyday lives are less often scrutinized as meaningful realities. Wishing to contribute to this research, we suggest that scholarly attention should also be directed to what makes all this political life possible. To this end, we propose that noticing political subjectivity as the condition of possibility of political agency, and topological polis as a geosocial context of political life, may be helpful in broadening the understanding of geopolitics as experienced, conceived, and practiced. We argue 
Authors' copy. The original article has been published in Geopolitics 17:1, doi:

10.1080/14650045.2016.1208654. For citation, please use the original.

that this approach has particular potential for identifying and examining new socio-spatial constellations in and through which politicizations take place. Moreover, we believe that it will help in appreciating the mundane politics of acts and actors that may first seem politically irrelevant, and thus in acknowledging matters and issues significant to people whose concerns do not easily enter the geopolitical stage. All these aspects work towards a more pluralistic understanding of politics as contextual importance unfolding in people's lived realities.

As an example, this article has introduced these ideas in the context of one major geopolitical development, the democratization that has sought to take root in the Arab world since late 2010, with influence on many other geopolitical developments worldwide. During the writing of the article the Tunisian National Dialogue Quartet that has navigated this process through the past rather chaotic years, was awarded the Nobel Peace Prize. The Committee emphasized that the prize was not for the four involved organizations, but to the composition that they had created. Like the protestors that the Jasmin Revolution brought together, they represent different quarters of the Tunisian society: Working life and welfare, principles of the rule of law, and human rights. The specific strengths that appeared in the connective activities during the winter of 2010-2011 thus seem to uphold in Tunisia, helping the country to build a democracy on the ruins of a society left behind by the former autocratic regime.

Using this empirical context and specifically M ohamed Bouazizi's exceptional life history as an example, we have argued that when understood as contextual importance, politics emerges as a mundane part of people's lives where attentiveness to personal grievances may sometimes lead to awareness of and action on broader societal injustice through connective and collective mobilization. It involves individual people with their personal interests; groups connected by amiable relations; people with shared cultural, ethnic, or religious ties; networks of people who share similar interests; groups of people who share their lives in practice; loosely connected crowds that come together occasionally; organized collectives involved in intentional activities; different medias and various actors who produce and disseminate mediated information; formal institutions and individual actors in them; states and their public administrative and politico-legal systems; non-governmental agencies with local, national, and international scope; and so on. Yet, even though the end of Mohamed Bouazizi's life took on extraordinary significance in events that unfolded, we do not wish to celebrate this as an exceptional case of mundane politics. On the contrary, what was exceptional in the case was merely the magnitude of the ramifications of his last action in the polis of the streets of Sidi Bouzid, not his political subjectivity that prompted attentiveness to the wrong that he could no longer bear to live with. It is precisely in this sense, through our attentiveness to social power 
Authors' copy. The original article has been published in Geopolitics 17:1, doi:

10.1080/14650045.2016.1208654. For citation, please use the original.

relations embedded in subject positions that we may accept, avert, or seek to transform, that "we

are all M ohamed Bouazizi". 62

\section{Acknowledgements}

We wish to thank the editors of Geopolitics, Katharyne Mitchell as an editor of this special issue, and the three anonymous referees for their helpful suggestions and constructive engagement with our work. We are also grateful to our inspiring colleagues in the Space and Political Agency Research Group and the RELATE Centre of Excellence, and to the Academy of Finland for funding our research (grants SA258341, SA272168).

\section{Notes}

${ }^{1} \mathrm{H}$. Ayeb, 'Social and Political Geography of the Tunisian Revolution: The Alfa Grass Revolution', Review of African Political Economy 38/129 (2011) pp. 467-479; D. Fassin, 'The Trace: Violence, Truth, and the politics of the Body', Social Research (2011) pp. 281-98; M. Mabrouk, 'A Revolution for Dignity and Freedom: Preliminary Observations on the Social and Cultural Background to the Tunisian revolution', The Journal of North African Studies (2011) pp. 625-635; M. Lim, 'Framing Bouazizi: 'White lies', Hybrid Network, and Collective/Connective Action in the 2010-11 Tunisian Uprising', Journalism 14/7 (2013) pp. 921-41; W. Greffrath and A. Duvenhage, 'The Arab Spring: Theoretical Perspectives on the Regimes of North Africa and the Middle East', South African Journal of International Affairs 21/1 (2014) pp. 27-44, see also V. Mamadouh,' Making Sense of Ongoing Revolutions: Geopolitical and Other Analyses of the Wave of Arab Uprisings Since December 2010', Geopolitics 18/3 (2013) pp.), 742-750.

2 P.N. Howard and M. M. Hussain, 'The Role of Digital Media', Journal of Democracy 22/3 (2011) pp. 35-48; N.B. $\mathrm{Nti}$, 'Lessons from the Death of a Tunisian Salesman: A Commentary', African Security Review 22/2 (2013) pp. 78-84; Greffrath and Duvenhage (note 1); T. Kharroub and B. Ozen Bas, 'Social M edia and Protests: An Examination of Twitter Images of the 2011 Egyptian Revolution', New Media \& Society (2015) pp. 1-20; A.E. Sakhawy, 'Is the Arab Spring Enough?', Peace Review 27/3 (2015) pp. 363-70.

${ }^{3}$ Here we deliberately avoid the term self-immolation that most commentators use to characterize Bouazizi's act because the concept has connotations that frame suicide as a calculated political statement (i.e. sacrificing oneself as a political protest). In what follows we set out to discuss where the politics of the act might lie instead of assuming it from the outset.

${ }^{4}$ Fassin (note 1).

${ }^{5} \operatorname{Lim}$ (note 1 ).

${ }^{6}$ I. Hamdan, Images of Revolution (Doha: Al Jazeera English 2012). [film]

${ }^{7} \operatorname{Lim}($ note 1) p. 927, 937.

${ }^{8} \operatorname{Lim}($ note 1$)$.

${ }^{9}$ H. De Soto, 'The Real M ohamed Bouazizi', Foreign Policy (Dec. 2011) http://foreignpolicy.com/2011/12/16/the-real-mohamed-bouazizi/

${ }^{10}$ For Tunisian informal economy, see J. Frische, "“Getting By" at the Urban Periphery: Everyday Struggles of Informal Merchants in Tunisia', Middle East-Topics \& Arguments 5 (2015) pp. 65-76.

${ }^{11}$ De Soto (note 9).

${ }^{12}$ E.g. A.J. Secor, 'Toward a Feminist Counter-Geopolitics: Gender, Space and Islamist Politics in Istanbul', Space and Polity 5/3 (2001) pp. 191-211; C. Desbiens, A. M ountz and M. Walton-Roberts, 'Introduction: Reconceptualizing the State from the M argins of Political Geography', Political Geography 23/ 3 (2004) pp. 241243; B. Gökarıksel, 'The Intimate Politics of Secularism and the Headscarf: The Mall, the Neighbourhood, and the Public Square in Istanbul', Gender, Place \& Culture 19/1 (2012) pp. 1-20; V. A. M assaro and J. Williams, 'Feminist Geopolitics', Geography Compass 7/8 (2013) pp. 567-577; D. M arshall, 'All the Beautiful Things: Trauma, Aesthetics and the Politics of Palestinian Childhood', Space and Polity 17/ 1 (2013) pp. 53-75; L. Staeheli and C.R. Nagel, 'Whose Awakening Is It? Youth and the Geopolitics of Civic Engagement in the 'Arab 
Authors' copy. The original article has been published in Geopolitics 17:1, doi: $10.1080 / 14650045.2016 .1208654$. For citation, please use the original.

Awakening", European Urban and Regional Studies 20/1 (2013) pp. 115-119; S. Laketa, 'Youth as Geopolitical Subjects: The Case of M ostar, Bosnia and Herzegovina', in K.P. Kallio and S. Mills (eds.), Geographies of Children and Young People: Politics, Citizenship and Rights. Vol. 7 of Skelton, T. (ed.) Geographies of Children and Young People. Berlin: Springer.

${ }^{13}$ E.g. J-A. Boudreau, N. Boucher and M. Liguori, 'Taking the Bus Daily and Demonstrating on Sunday: Reflections on the Formation of Political Subjectivity in an Urban World, City 13/2-3 (2009) pp. 336-46; A. Carvalho, 'Media(ted) Discourses and Climate Change: A Focus on Political Subjectivity and (Dis)engagement', Wiley Interdisciplinary Reviews: Climate Change 1/2 (2010) pp. 172-79; E.F. Isin, 'Citizenship in Flux: The Figure of the Activist Citizen', Subjectivity 29/1 (2009) pp. 367-88; E.F. Isin, Citizens Without Frontiers (Bloomsbury Publishing: USA 2012); M. Jarman, S. Lamp, D. M itchell, D. Nepveux, N. Nowell and S. Snyder, 'Theorising Disability as Political Subjectivity: Work by the UIC Disability Collective on Political Subjectivities', Disability \& Society 17/5 (2002) pp. 555-69; C. Taylor, 'The Politics of Recognition', in A. Gutmann (ed.), Multiculturalism: Examining the Politics of Recognition. (Princeton, NJ: PUP 1994) pp. 25-73.

${ }^{14} \mathrm{C}$. Barnett, 'Deconstructing Radical Democracy: Articulation, Representation and Being-With-Others', Political Geography 23/5: (2004) pp. 503-28; M. Dikeç, 'Space, Politics, and the Political', Environment and Planning D: Society and Space 23/2 (2005) 171-88; M. Dikeç, 'Beginners and Equals: Political Subjectivity in Arendt and Rancière', Transactions of the Institute of British Geographers 38/1 (2013) pp. 78-90; Z. Gambetti, 'The Agent Is the Void! From the Subjected Subject to the Subject of Action', Rethinking Marxism 17/3 (2005) pp. 425-37; J. Glynos and Y. Stavrakakis 'Lacan and Political Subjectivity: Fantasy and Enjoyment in Psychoanalysis and Political Theory', Subjectivity 24/1 (2008) pp. 256-74; H. Hawkins, 'Dialogues and Doings: Sketching the Relationships between Geography and Art' Geography Compass 5/7 (2011) pp. 464-78; J. Sharp, 'Geography and Gender: Finding Feminist Political Geographies', Progress in Human Geography 31/3 (2007) pp. 381-87; L.A. Staeheli and D. Hammett, 'Educating the New National Citizen: Education, Political Subjectivity and Divided Societies', Citizenship Studies 14/6 (2010) pp. 667-80.

${ }^{15}$ Laura Zanotti criticizes substantialist ontology for its underlying "liberal conceptualization of subjects and power as standing in a relation of externality [that] stifles the possibility of reimagining political agency on different grounds [...] presupposes that power and subjects are entities possessing qualities that preexist relations. Power is imagined as a 'mighty totality', and subjects as monads endowed with potentia. As a result, the problematique of political agency is portrayed as a quest for the "liberation" of a subject ontologically gifted with a freedom that power inevitably oppresses. In this way, the conceptualization of political agency remains confined within the liberal struggle of 'freedom' and "oppression'." L. Zanotti, 'Governmentality, Ontology, M ethodology: Re-thinking Political Agency in the Global World', Alternatives: Global, Local, Political 38/4 (2013) pp. 288-304. See also J. Häkli, E. Pascucci and K. P. Kallio, 'Becoming Refugee in Cairo: The Political in Performativity', International Political Sociology [in process]; K. P. Kallio, 'Shaping Subjects in Everyday Encounters: Intergenerational Recognition in Intersubjective Socialisation', Environment and Planning D: Society and Space [in press, DOI: 10.1177/ 0263775816654916]; M. Joronen and J. Häkli, 'Politicizing Ontology', Progress in Human Geography [online first, DOI: 10.1177/0309132516652953].

${ }^{16}$ S. R. Kirschner, 'The M any Challenges of Theorizing Subjectivity', Culture \& Psychology, 19/2 (2013) p. 226.

${ }^{17}$ G. H. M ead, 'M ind, Self, and Society. C. W. M orris (ed). (Chicago: UChP, 1932); see also V. Colapietro, 'Practice, Agency, and Sociality: An Orthogonal Reading of Classical Pragmatism', International Journal for Dialogical Science, 1/ 1 (2006) pp. 23-31; D. Cornell and S. Murphy, 'Anti-Racism, Multiculturalism and the Ethics of Identification', Philosophy \& Social Criticism, 28/4 (2002) pp. 419-49; C. Heyes, 'Can There be a Queer Politics of Eecognition?', in R. Fiore and H. Nelson (eds.), Recognition, Responsibility, and Rights: Feminist Ethics and Social Theory (Lanham: Rowman \& Littlefield) pp. 53-66; A. Honneth, The struggle for Recognition: The Moral Grammar of Social Conflicts (Cambridge: Polity Press).

${ }^{18}$ For a full discussion, see J. Häkli and K. P. Kallio, 'Subject, Action and Polis: Theorizing Political Agency', Progress in Human Geography, 38/2, (2014) pp. 181-200.

${ }^{19}$ See also C. Rossdale 'Occupying Subjectivity: Being and Becoming Radical in the Twenty-First Century: Introduction', Globalizations 12/ 1 (2015) pp. 1-5, and Faria \& M ollett's discussion on 'whiteness', C. Faria and S. Mollett, 'Critical Feminist Reflexivity and the Politics of Whiteness in the 'Field', Gender, Place \& Culture, 23/1 (2016) 79-93.

${ }^{20} \mathrm{~S}$. Shukaitis, Imaginal M achines: Autonomy and Self-Organization in the Revolutions of Everyday Life (Brooklyn, NY: Autonomedia/M inor Compositions, 2009); C. Rossdale 'Enclosing Critique: The Limits of Ontological Security', International Political Sociology, 9/4 (2015) pp. 369-386; Häkli and Kallio (note 18). ${ }^{21}$ C. R. Jørgensen, 'Disturbed Sense of Identity in Borderline Personality Disorder', Lournal of Personality Disorders, 20/6 (2006) p. 620, 622. 
Authors' copy. The original article has been published in Geopolitics 17:1, doi: 10.1080/14650045.2016.1208654. For citation, please use the original.

${ }^{22}$ E. H. Erikson, Identity and the Life Cycle (New York: IUP, 1959); O. Kernberg, Object Relations Theory and Clinical Psychoanalysis (New York: Aronson, 1976).

${ }^{23}$ E.g. A. Yeatman, 'The Subject of Citizenship', Citizenship Studies 11/1 (2007) pp. 105-115.

${ }^{24}$ H. Arendt, The Human Condition (Chicago: UCP, 1958) p. 8.

${ }^{25}$ See, for example M. Crossley and N. Crossley "'Patient" voices, social movements and the habitus; how psychiatric survivors "speak out"', Social Science \& M edicine, 52/10 (2001) pp. 1477-1489.

${ }^{26}$ Arendt (note 24, p. 198).

${ }^{27}$ E.g. M. Dikeç (note 14); S. Elden, 'The Place of the Polis: Political Blindness in Judith Butler's Antigone's

Claim', Theory \& Event 8/1 (2005); J. Ely, 'The Polis and 'the Political': Civic and Territorial Views of Association', Thesis Eleven 46/1 (1996) pp. 33-65; D.L. M arshall, 'The Polis and its Analogues in the Thought of Hannah Arendt', Modern Intellectual History 7/1 (2010) pp. 123-49; Häkli and Kallio (note 18).

${ }^{28}$ M abrouk (note 1), p.625; see also A. Zevnik, 'M aze of Resistance: Crowd, Space and the Politics of Resisting Subjectivity', Globalizations 12/1 (2015) pp. 101-115.

${ }^{29} \mathrm{See}$, for example, how Bouazizi's life is framed in the analyses by Ayeb (note 1) and A. Graziano, 'The Tunisian Diaspora: Between 'Digital Riots' and Web Activism', Social Science Information 51/4 (2012) pp. 534-550.

${ }^{30}$ Temporality is an important dimension of contextual politicization, the constitution of polis and the becoming of political subjects. Due to space constraints, we cannot discuss the issue in-depth in this paper but do so elsewhere (Häkli and Kallio, 'On Becoming Political: Studying the Political Ordinary', manuscript). See also M. Emirbayer and A. Mische, 'What is agency?' American Journal of Sociology, 103/4 (1998), pp. 962-1023.

${ }^{31}$ De Soto (note 9).

${ }^{32} \mathrm{~J}$. Frische, "'Getting By" at the Urban Periphery: Everyday Struggles of Informal Merchants in Tunisia', Middle East-Topics \& Arguments, 5 (2015) pp. 65-76.

${ }^{33}$ For further details on the practices of informal economy, see H. Ilahiane, J Sherry, 'Joutia: Street Vendor Entrepreneurship and the Informal Economy of Information and Communication Technologies in M orocco', The Lournal of North African Studies 13/2 (2008) 243-255.

${ }^{34}$ Frische (note 32) p. 69.

${ }^{35}$ For example J. R. Halverson, S. W. Ruston and A. Trethewey, 'M ediated M artyrs of the Arab Spring: New Media, Civil Religion, and Narrative in Tunisia and Egypt', Lournal of Communication, 63/2 (2013) pp. 312-32; Howard and Hussain (note 2); Greffrath and Duvenhage (note 1).

${ }^{36}$ Frische (note 32) p. 74.

${ }^{37}$ H. Leitner, E. Sheppard and K. M. Sziarto, 'The Spatialities of Contentious Politics', Transactions of the Institute of British Geographers 33/2 (2008) pp. 157-172; J. Allen, 'Topological Twists: Power's Shifting Geographies', Dialogues in Human Geography 1/3 (2011) pp. 283-298; P. Giaccaria and C. M inca,

'Topographies/Topologies of the Camp: Auschwitz as a Spatial Threshold', Political Geography 30/1 (2011) pp. 3-12 ; L. M artin and A. J. Secor, 'Towards a Post-M athematical Topology', Progress in Human Geography 38/3 (2014) pp. 420-438.

${ }^{38} \mathrm{Lim}$ (note 1); for suicidal politicality, see also N. M ichelsen, 'The Political Subject of Self-immolation', Globalizations 12/1 (2015) pp. 83-100.

${ }^{39}$ Michelsen (note 38).

${ }^{40}$ E.g. Ayeb (note 1), Greffrath and Duvenhage (note 1), Kharroub and Ozen Bas (note 2), Mabrouk (note 1).

${ }^{41} \operatorname{Lim}$ (note 1).

${ }^{42}$ Howard and Hussain (note 2); Halverson et al. (note 35).

${ }^{43}$ W. L. Bennett and A. Segerberg, 'The Logic of Connective Action: Digital M edia and the Personalization of Contentious Politics', Information, Communication \& Society, 15/5 (2012) pp. 739-68; Lim (note 1).

${ }^{44}$ J. S. Ismael and S. T. Ismael, 'The Arab Spring and the Uncivil State', Arab Studies Quarterly, 35/3 (2013) 22940.

${ }^{45} \mathrm{~S}$. Seidman and C. M eeks, 'The Politics of Authenticity: Civic Individualism and the Cultural Roots of Gay Normalization', Cultural Sociology, 5/4 (2011) pp. 519-36.

${ }^{46}$ Arendt (note 24) p. 177.

${ }^{47}$ For an example of deliberate politicization, see K. M itchell, and S. Elwood, 'Intergenerational M apping and the Cultural Politics of M emory', Space and Polity 17/1 (2013) pp. 33-52.

${ }^{48}$ For thorough discussions on political subject formation in different empirical contexts, see K.P. Kallio and J. Häkli., 'Children and Young People's Politics in Everyday Life', Space and Polity 17/ 1 (2013) pp. 1-16., K. P. Kallio, 'Rethinking Spatial Socialization as a Dynamic and Relational Process of Political Becoming', Global Studies of Childhood 4/3 (2014) pp. 210-223., Häkli and Kallio (note 18), Häkli, Pascucci and Kallio (note 15), Kallio (note 15). 
Authors' copy. The original article has been published in Geopolitics 17:1, doi: 10.1080/14650045.2016.1208654. For citation, please use the original.

\footnotetext{
${ }^{49} \mathrm{~A}$ failure in this communication may lead to what she calls hermeneutical injustice, that is, "the lived experience of being unfairly disadvantaged in rendering one's social experiences intelligible, to others and possibly even to oneself” M. Fricker, 'Précis' Theoria, 23/1 (2008) pp. 69-71. See also M. Fricker, Epistemic Injustice: Power and the Ethics of Knowing (Oxford: Oxford University Press, 2007).

${ }^{50}$ Ayeb (note 1), p. 470.

${ }^{51}$ Frische (note 32) p. 65.

${ }^{52}$ A. Bayat, 'Plebeians of the Arab Spring', Current Anthropology 56/11 (2015) pp. 33-43., E. Martin, 'On One Forgotten Cause of the Arab Spring: The Lack of Economic Freedom', Economic Affairs 32/3 (2012) 94-96., cf. Ilahiane and Sherry (note 28)

${ }^{53}$ De Soto (note 9$)$.

${ }^{54}$ Ayeb (note 1), p.472, Frische (note 32) pp. 71-73.

${ }^{55}$ De Soto (note 9 ).

${ }^{56}$ M. M abrouk (note 1); S. Al Ismaily, M. Cervantes \& F. M cMahon, 'Economic Freedom of the Arab World: 2011 Annual Report', Fraser Institute (2011) http://www.fraserinstitute. org. Visited 4.3.2016., see also N.B. Oman, 'The Arab World Needs Free M arkets as M uch as Democracy' Deseret News, 12.3.2011.

http://scholarship.law.wm.edu/cgi/viewcontent.cgi?article=1234\&context=popular_media. Visited 4.3.2016.

${ }^{57}$ De Soto (note 9 ).

${ }^{58}$ See e.g. Leitner, Sheppard and Sziarto (note 37); Bennett and Segerberg (note 43); M itchell and Elwood (note 47); Zevnik (note 28); Fricker (note 49).

${ }^{59}$ Lim (note 1), see also D. Huber \& L. Kamel 'Arab Spring: The Role of the Peripheries', Mediterranean Politics 20/2 (2015) pp. 127-141; Halverson et al. (note 35).

${ }^{60}$ See also Zevnik (note 28), p. 105.

${ }^{61} \mathrm{Cf}$. Isin (note 13).

${ }^{62}$ S. Buck-M orss, 'Democracy: An Unfinished Project', boundary 2 41/2 (2014) pp. 71-98.
} 